\title{
Studi Bahaya Antropogenik yang Disebabkan Pembuangan Sampah di Bentuklahan Fluvio-Marin di Sebagian Muara Angke, Jakarta Menggunakan Data Penginderaan Jauh Udara
}

\author{
Study of Anthropogenic Hazard Caused by Waste Disposal in Fluvio-Marine Landform \\ in Part of Muara Angke, Jakarta Using Aerial Remote Sensing Data
}

Nurwita Mustika Sari,2, Mangapul Parlindungan Tambunan²

Diterima: 1 November 2019

Disetujui: 30 Maret 2020

\begin{abstract}
Abstrak: Bahaya antropogenik merupakan bahaya yang timbul akibat perbuatan atau kesalahan yang dilakukan manusia. Bahaya antropogenik dapat berdampak pada manusia maupun ekosistem yang lebih luas dan pada berbagai bentuklahan. Sampah sebagai buangan manusia adalah permasalahan besar di perkotaan terkait dengan sulitnya pengelolaan sampah sementara produksi sampah terus meningkat. Dampak dari pengelolaan sampah yang buruk di kota membuatnya menjadi potensi bahaya antropogenik bagi wilayah tersebut. Salah satu area kota yang kerap kurang mendapat perhatian terkait sampah atau sanitasi lingkungan dan telah terkena dampak negatif sampah adalah pesisir di kota besar yang merupakan bagian bentuklahan fluvio-marin, salah satunya yaitu Muara Angke yang menjadi wilayah kajian penelitian ini. Identifikasi lokasi pembuangan sampah penting dilakukan untuk mengetahui tingkat bahaya antropogenik yang ditimbulkan sampah di area tersebut. Dengan resolusi spasial saangat tinggi yang dimiliki data penginderaan jauh udara, identifikasi objek di perkotaan seperti lokasi pembuangan sampah dapat dilakukan. Tujuan penelitian ini adalah mengidentifikasi lokasi pembuangan di sebagian Wilayah Muara Angke dan mengidentifikasi potensi bahaya antropogenik akibat sampah di wilayah tersebut. Data yang digunakan adalah data kamera pesawat tanpa awak LSU (LAPAN Surveillance UAV). Metode yang digunakan dalam penelitian ini adalah interpretasi visual data kamera LSU. Hasil menunjukkan bahwa dapat dilakukan identifikasi lokasi pembuangan sampah dengan menggunakan data penginderaan jauh udara dan interpretasi visual terhadap data tersebut.
\end{abstract}

Kata kunci: Bahaya antropogenik, sampah, penginderaan jauh udara, interpretasi visual, bentuklahan fluvio-marin

\begin{abstract}
Anthropogenic hazards are hazards arising from human actions or negligences. Anthropogenic hazards can affect both human and the broader ecosystem and various landforms. Waste as the effect of human activity is a big problem in urban areas related to the difficulty of waste management while waste production continues to increase. The impact of poor waste management in the city is a potential anthropogenic hazard for the region. Part of the city that often receives less attention related to waste or environmental sanitation and has been negatively affected by waste is the coastal area in a big city, which is kind of fluvio-marine landform unit,
\end{abstract}

\footnotetext{
${ }^{1}$ Pusat Pemanfaatan Penginderaan Jauh LAPAN

${ }^{2}$ Prodi Magister Ilmu Geografi, Fakultas Matematika dan Ilmu Pengetahuan Alam Universitas Indonesia
} 
one of which is Muara Angke, which is the study area of this research. Identification of the waste disposal site is carried out to determine the level of anthropogenic hazard posed by waste in the area. With very high spatial resolution obtained by aerial remote sensing data, identification of objects in urban areas such as waste disposal site can be conducted. The purpose of this study is to identify the waste disposal site in part of Muara Angke region and to identify the potential of anthropogenic hazard caused by waste in the area. The data used is the LSU (LAPAN Surveillance UAV) camera data. The method proposed in this research is visual interpretation LSU camera data. The result showed that waste disposal location can be performed using aerial remote sensing data and visual interpretation to the data.

Keywords: Anthropogenic hazards; waste; aerial remote sensing; visual interpretation; fluviomarine landforms

\section{PENDAHULUAN}

Bahaya dan bencana antropogenik yang disebabkan oleh kelalaian ataupun kesalahan manusia dapat menyebabkan dampak yang tidak kalah besar dibandingkan bencana alam. Bahaya dan bencana antropogenik dapat berupa bencana teknologi seperti kecelakaan transportasi, bencana lingkungan dan bencana kerekayasaan, dan dapat juga berupa bencana sosial seperti kriminal, kerusuhan dan perang (Jha, 2010). Beberapa bencana antropogenik yang pernah terjadi diantaranya api dari pipa gas GAIL di India (Lakshmi \& Kumar, 2015) yang menyebabkan 23 korban jiwa. Bencana antropogenik akibat perilaku manusia dan menimbulkan korban jiwa lain yang menjadi perhatian global adalah terorisme, kerusuhan, perang besar serta kecelakaan industri (Powers et al., 2019).

Faktor antropogenik dapat menimbulkan bahaya di berbagai bentuklahan diantaranya bentuklahan karst yang sangat rentan mengalami kerusakan akibat kegiatan manusia (Parise, Waele, \& Gutierrez, 2009). Kegiatan yang dilakukan oleh manusia di DAS yang ada di bentuklahan karst juga mempengaruhi air tanah dan air permukaan di daerah tersebut bahkan rentan menimbulkan longsor (Bonacci, 2004). Kerusakan bentuklahan karst karena faktor antropogenik juga dikaji oleh (Day, 2007) di wilayah Jamaika yang rentan menimbulkan penurunan permukaan karena infrastruktur di atasnya, juga perubahan karst alam karena manusia di Italia Selatan (Andriani \& Walsh, 2009). Bahaya lain dapat timbul di bentuklahan marin khususnya satuan bentuklahan gisik akibat eksploitasi parwisata dan perpindahan penduduk ke wilayah pantai serta polusi di area gisik (Lozoya, Sarda, \& Jimenez, 2011). Bahaya antropogenik di wilayah pantai yang diakibatkan ramainya turis di wilayah pantai juga terjadi di pantai-pantai Amazon, yang menyebabkan polusi, kebisingan, kerentanan kecelakaan hingga kerusakan wilayah pantai (Pereira, Vila-concejo, da Costa, \& Short, 2014).

Kota merupakan area vital suatu negara karena menjadi pusat kegiatan sosial, ekonomi hingga pemerintahan. Dengan predikat kota sebagai pusat kegiatan di suatu wilayah maka kepadatan penduduk di kota pasti tinggi. Hal ini menimbulkan permasalahan tersendiri seperti pemekaran kota yang tidak terkendali (urban sprawl) yang tentunya memberikan dampak meluas pada lingkup ekologi, sosial dan lingkungan (Du, 2016). Permasalahan lain yang muncul di area perkotaan ialah terjadinya kemacetan lalu lintas (Astuti \& Farda, 2015). Tidak hanya itu, permasalahan lain yaitu terkait penurunan kualitas kesehatan lingkungan akibat tingginya produksi sampah di wilayah perkotaan oleh aktivitas dan gaya hidup manusia (Mulasari, Husodo, \& Muhadjir, 2016). Produksi sampah yang tinggi di kota memicu munculnya titik-titik lokasi pembuangan sampah di suatu wilayah. Keberadaan lokasi pembuangan sampah ini mempengaruhi aspek sanitasi lingkungan dan estetika.

Sebagian wilayah Muara Angke merupakan salah satu area pesisir di kota besar tepatnya di Jakarta Utara yang mengalami permasalahan lingkungan. Wilayah ini merupakan wilayah pelabuhan bagi kapal ikan atau kapal nelayan, termasuk kampung nelayan dan tempat pelelangan ikan dengan kepadatan permukiman sangat tinggi. 
Kepadatan penduduk yang tinggi ini membuat produksi sampah sangat besar. Berbagai dampak negatif telah dirasakan masyarakat yang tinggal di wilayah Muara Angke akibat pencemaran oleh sampah. Hal ini diperburuk dengan pengetahuan yang kurang dan tidak adanya perilaku preventif dalam penghadapi penyakit tertentu seperti Infeksi Saluran Pernafasan Akut (ISPA) di sana (Silviana, 2014), padahal kondisi udara wilayah Muara Angke akibat sampah potensial menimbulkan ISPA. Hal lain yang rentan terdampak oleh pencemaran sampah selain dari sisi manusia adalah ekosistem pada bentuklahan fluviomarin pada sepanjang sungai yang bermuara di pantai Muara Angke.

Salah satu teknologi yang dapat digunakan untuk melakukan pemantauan terhadap wilayah kota diantaranya adalah penginderaan jauh dengan resolusi spasial tinggi seperti penginderaan jauh udara. Studi pemanfaatan data penginderaan jauh resolusi spasial tinggi untuk melihat bagaimana kondisi permukiman di wilayah perkotaan telah dilakukan dan mampu membedakan kualitas permukiman hingga melihat bagaimana agihan permukiman kumuh di wilayah tersebut, bahkan objek vegetasi tunggal di perkotaan (Farizki \& Anurogo, 2017; Sari \& Kushardono, 2016; Sinaga, Gunawan, \& Zuharnen, 2016).

Penggunaan teknik penginderaan jauh dan SIG untuk kajian sampah pernah dilakukan untuk menjadi area rekomendasi TPA di kota Surabaya menggunakan data penginderaan jauh resolusi spasial menengah Landsat dan foto udara hitam putih dan di kota Padang menggunakan data Landsat dan metode SIG (Audina, Anwar, \& Antomi, 2018; Setiawan, 2010).

Resolusi data penginderaan jauh sangat tinggi membuat objek yang tampak dalam citra tersebut terlihat dengan jelas. Teknik interpretasi visual terhadap data penginderaan jauh udara dapat dilakukan untuk mengenali objek-objek yang ada di citra. Berdasarkan penelitian terdahulu, interpretasi visual terhadap lokasi pembuangan sampah belum dilakukan dengan menggunakan data penginderaan jauh resolusi sangat tinggi. Dalam penelitian ini akan dilakukan identifikasi lokasi pembuangan sampah di sebagian wilayah Muara Angke menggunakan data penginderaan jauh resolusi spasial sangat tinggi yang diakuisisi dengan pesawat tanpa awak buatan LAPAN yaitu LSU.

\section{Bahan dan Metode}

Data yang digunakan dalam penelitian ini adalah foto udara yang diakuisisi tim Pusat Teknologi Penerbangan LAPAN menggunakan pesawat LAPAN Surveillance UAV (LSU) pada tanggal 5 Oktober 2017. Data diambil dengan kamera Canon PowerShot S100 dan memiliki band RGB dengan tinggi terbang kurang lebih 170 meter. Area yang diakuisisi adalah sebagian wilayah Muara Angke, Jakarta Utara.

Tahap pengolahan data dalam penelitian ini dimulai dengan membuat citra orthomosaik dari data foto tunggal yang telah dihasilkan pada proses akuisisi di sebagian wilayah Muara Angke, Jakarta Utara dan tahapan disajikan dalam Gambar 1.

Citra orthomosaik dibuat dengan tahapan penyiapan data foto udara tunggal yang akan diolah, dalam arti memilah data berurutan, cukup bertampalan, tidak blur dan tidak oblique. Selanjutnya dilakukan tahapan pengolahan data align photos, build dense cloud, build mesh, build texture, build tiled model, build DEM dan build orthomosaic. Proses pembuatan citra termosaik ini dilakukan berulang kali hingga memperoleh hasil yang baik. Jika pada salah satu rangkaian proses ini hasil yang diperoleh kurang baik atau terjadi kegagalan proses maka pada tahap itu diulang dengan menggunakan tingkat yang berbeda untuk setiap parameter hingga memperoleh hasil terbaik. Pengulangan dari tahap proses ini tidak harus diulang dari awal jika hasil dari proses sebelum itu sudah disimpan, oleh karena itu hasil dari setiap tahap proses harus dipastikan sudah disimpan agar jika terjadi kesalahan di tengah-tengah proses, maka proses yang diulang tidak banyak dan memakan waktu.

Setelah dihasilkan citra termosaik sebagian wilayah Muara Angke, tahap selanjutnya adalah melakukan interpretasi visual terhadap objek-objek yang ada pada data citra dan 
mengidentifikasi lokasi pembuangan sampah di area kajian. Objek lain yang juga diamati untuk dianalisis secara keruangan adalah permukiman, lahan terbuka jalan, tubuh air dan vegetasi untuk melihat bagaimana sebaran dan pola objek tersebut di area kajian yang merupakan bentuklahan fluvio-marin.

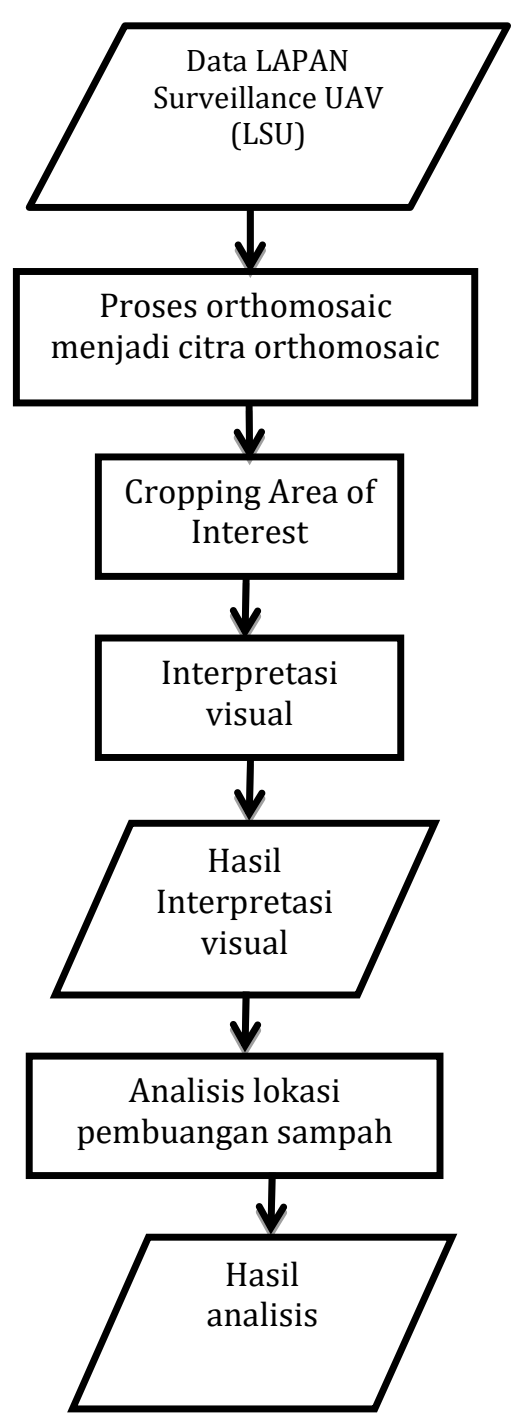

Gambar 1. Diagram alir penelitian

Identifikasi objek dilakukan dengan interpretasi visual secara penuh sebagaimana dilakukan (Ben-yosef, Assif, \& Ullman, 2018) yag mempelajari bagaimana struktur semantik objek.

Untuk konfigurasi minimal C, struktur semantik SC sebagai sepasang dari dua set: set komponen semantik PC yang disebutkan 'primitif', dan satu set hubungan antara primitif, dilambangkan oleh RC, yaitu 




Selanjutnya untuk mengenali objek dilakukan interpretasi visual berdasarkan kunci interpretasi terhadap objek di citra yang berbeda ((Yang et al., 2011), (Sari \& Kushardono, 2019)).

Tabel 1. Kunci interpretasi objek

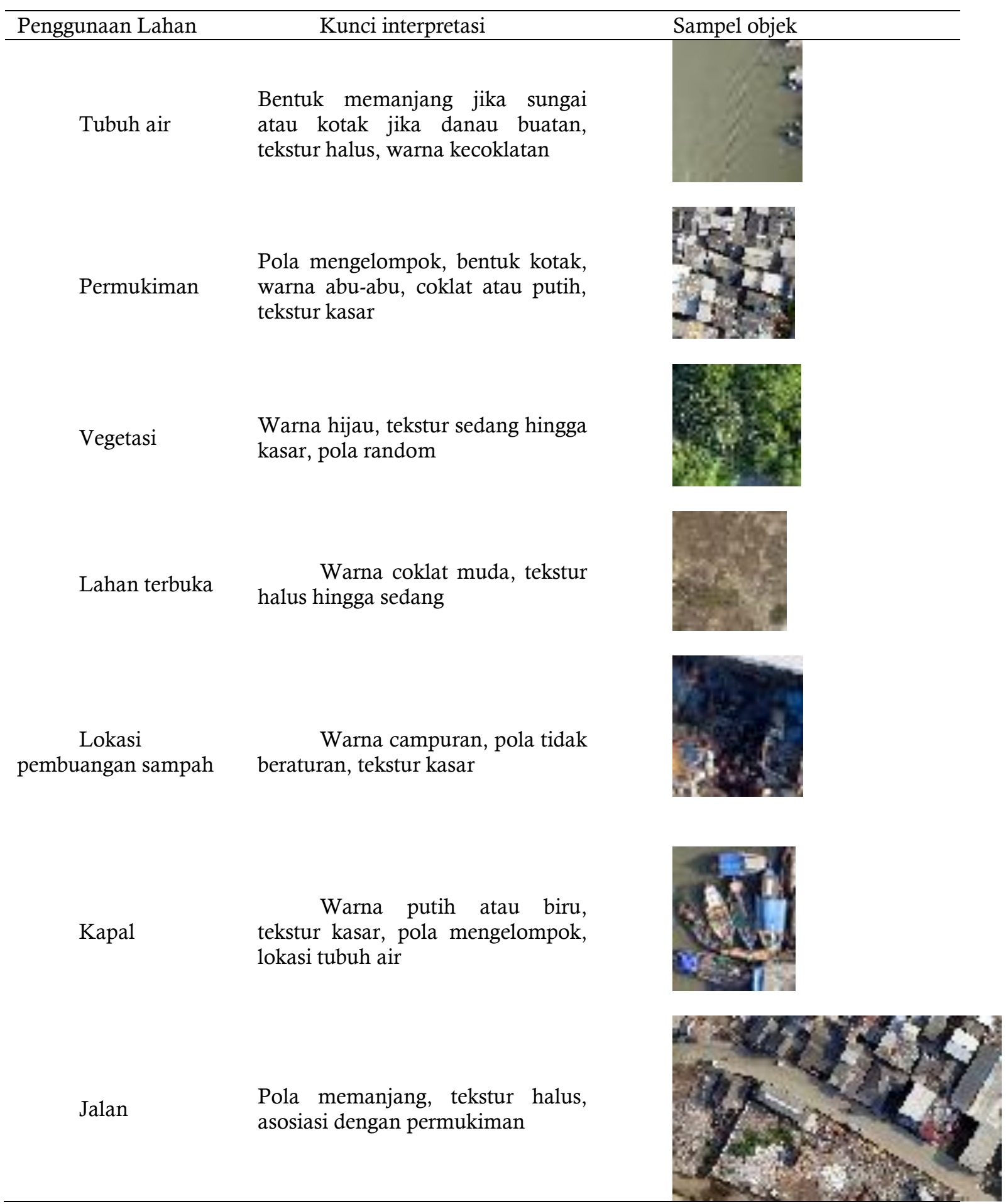


HASIL

Hasil pertama yang diperoleh adalah hasil pemotongan (cropping) area kajian yang sudah melalui proses orthomosaik dari foto-foto tunggal (Gambar 2).

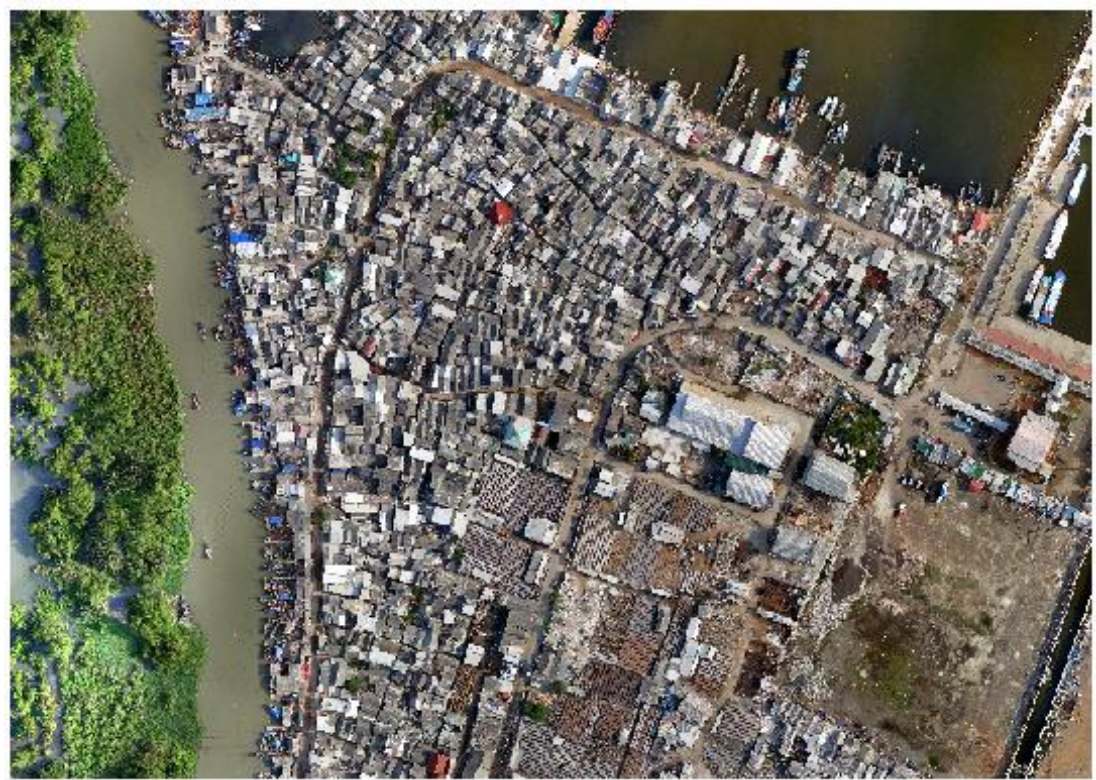

Sumber: Pengolahan, 2019

\section{Gambar 2. Citra Orthomosaic Data LSU}

Hasil kedua yang diperoleh adalah hasil identifikasi lokasi pembuangan sampah di wilayah kajian khususnya area permukiman (Gambar 3a, 3b, 3c).

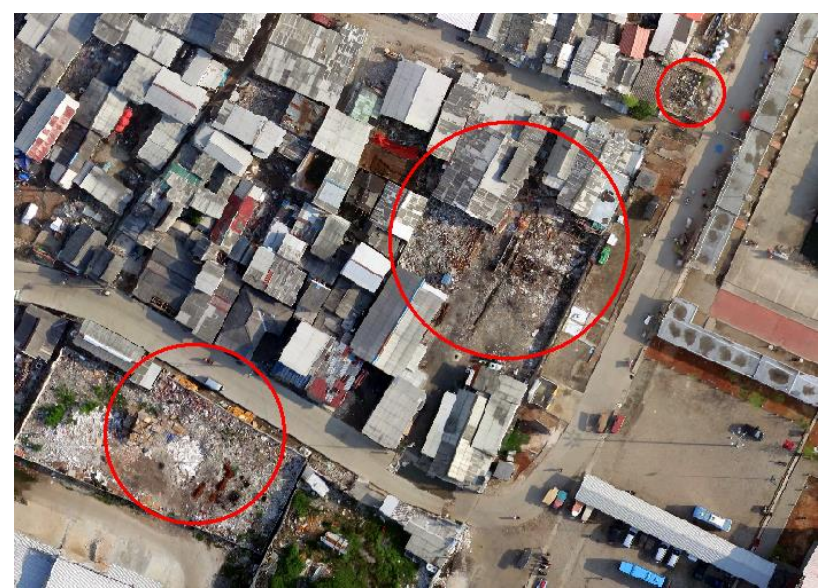

(a) 


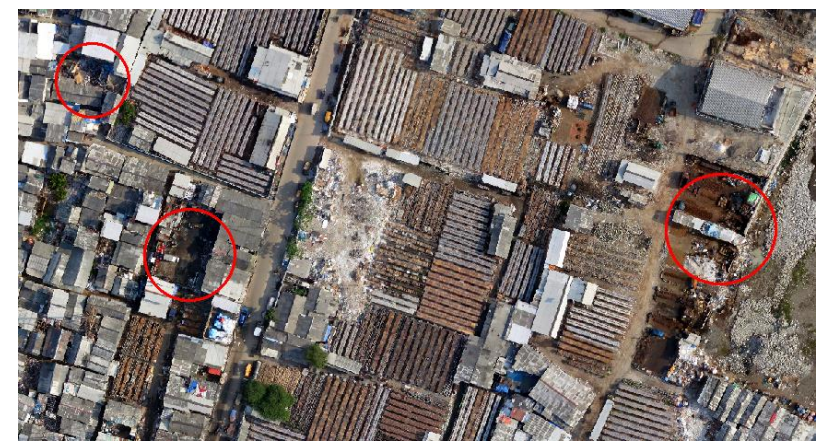

(b)

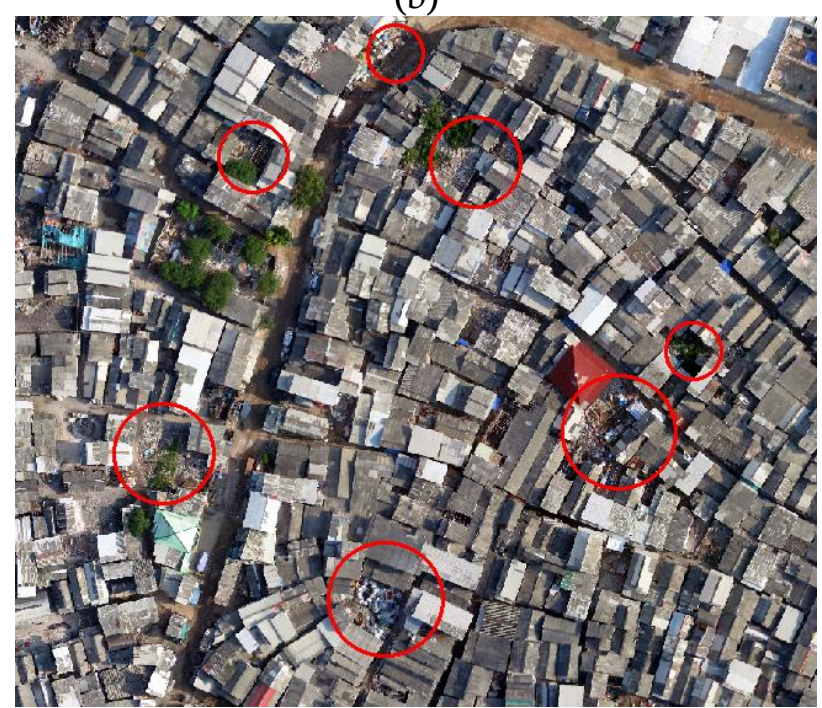

(c)

Sumber: Pengolahan, 2019

\section{Gambar 3. Hasil Identifikasi Lokasi Pembuangan Sampah di Area Permukiman}

Hasil ketiga yang diperoleh adalah hasil identifikasi pencemaran oleh sampah di wilayah kajian khususnya pada tubuh air atau sepanjang aliran sungai dan sekitar vegetasi mangrove (Gambar 4a, 4b, 4c).

\section{PEMBAHASAN}

Hasil pertama yang diperoleh adalah citra termosaik sebagian area Muara Angke, Jakarta. Dari citra tersebut terlihat jelas bahwa pada area kajian terdapat berbagai objek dan penggunaan lahan. Adapun objek dan penggunaan lahan yang dapat diidentifikasi berdasarkan kunci interpretasi sebagaimana Tabel 1 adalah tubuh air, permukiman, vegetasi, lahan terbuka, kapal, lokasi pembuangan sampah dan jalan. Dari citra termosaik dapat dilihat bahwa pola permukimannya tidak beraturan atau tidak tertata iddengan baik. Permukiman yang tampak pada citra merupakan bagian yang paling dekat dengan pantai sehingga unit bentuklahannya adalah beting gisik dan dataran pantai. Permukiman yang juga merupakan kampung nelayan dan Tempat Pelelangan Ikan (TPI) pada beberapa bagian terkesan kumuh.

Untuk tubuh air yang tampak adalah bagian laut Teluk Jakarta dan sungai yang alirannya bermuara ke Teluk Jakarta. Dari warna air dan beberapa objek mengapung di permukaan air nampak bahwa pencemaran air terjadi cukup parah di wilayah ini. Vegetasi yang nampak di sekitar sungai merupakan vegetasi mangrove yang merupakan komunitas riparian. 
Hasil kedua yaitu hasil identifikasi lokasi pembuangan sampah di area permukiman. Dari interpretasi visual pada bagian permukiman dapat dilihat bahwa lokasi pembuangan sampah terdapat pada berbagai tempat yang ditandai dengan lingkaran merah. Pola dari lokasi pembuangan sampah ini adalah random dengan luasan yang berbeda antara satu tempat dengan tempat lainnya. Bentuk, pola, warna serta tekstur dari lokasi pembuangan sampah yang khas ditambah dengan tingginya resolusi spasial data citra membuat identifikasi dapat dilakukan. Lokasi pembuangan sampah yang cukup banyak dan terdapat di tengah-tengah permukiman menunjukkan bahwa risiko pencemaran oleh sampah terhadap warga yang tinggal di sekitar Muara Angke sangat tinggi dan potensial menimbulkan bahaya antropogenik bagi penduduk yang tinggal di wilayah tersebut.

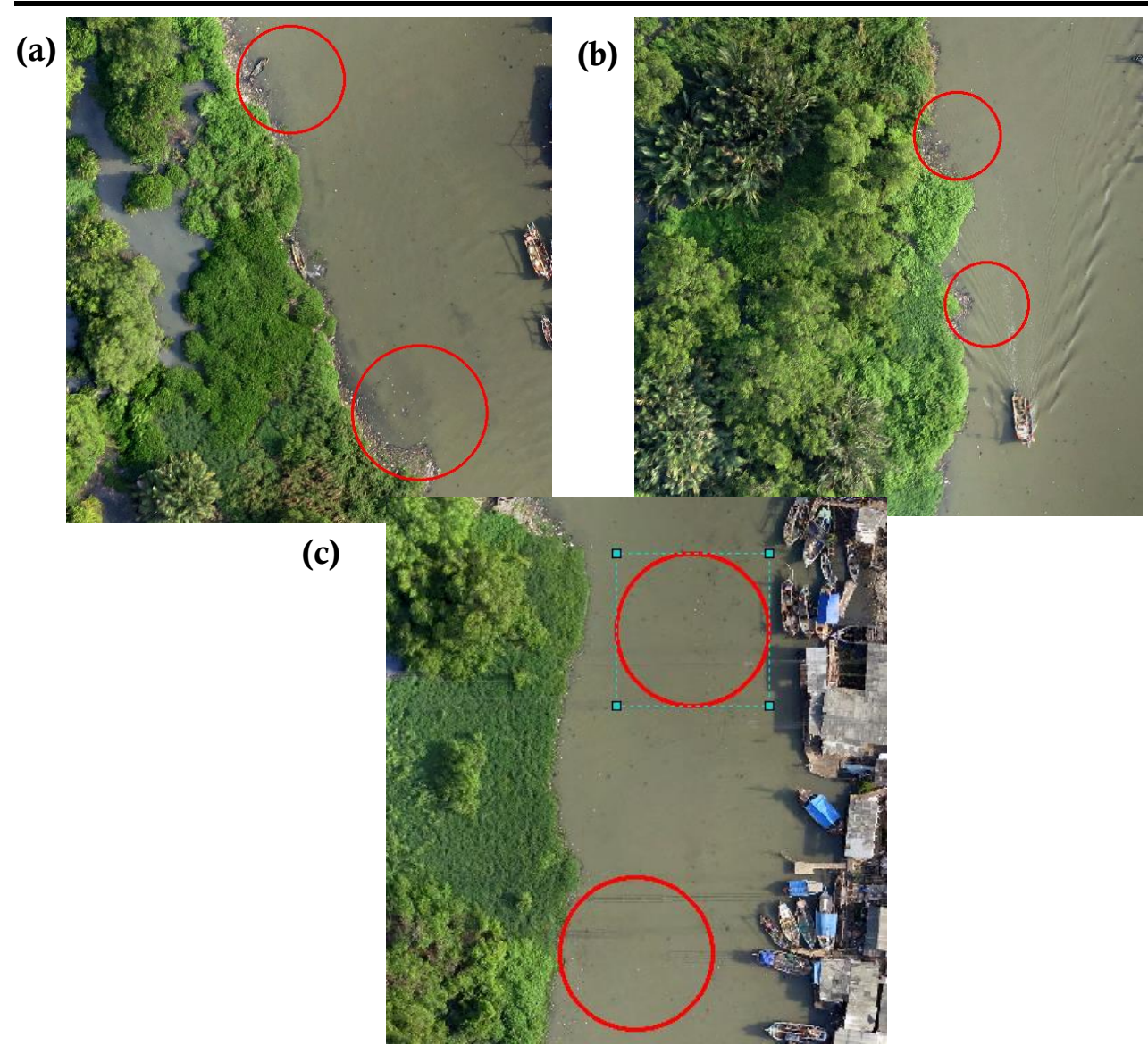

Sumber: Pengolahan, 2019

\section{Gambar 4. Hasil Identifikasi Lokasi Pembuangan Sampah di Tubuh Air dan Vegetasi Mangrove}

Hasil ketiga yaitu hasi identifikasi lokasi pembuangan sampah di tubuh air dan di sekitar komunitas riparian diantaranya vegetasi mangrove. Dari area yang diamati terlihat bahwa pencemaran oleh sampah yang dibuang ke sungai dan sekitar wilayah Teluk Jakarta terjadi cukup signifikan hingga terlihat jelas dari citra. Objek di air yang terlihat merupakan pencemar yang sangat berbahaya bagi komunitas di sekitar pencemaran terjadi. Bahaya ini ditunjukkan dengan penelitian oleh (Hamzah \& Setiawan, 2010) yang menunjukkan 
bahwa pada bagian mangrove yang tumbuh di sekitar Muara Angke terdapat kandungan logam berat $\mathrm{Cu}, \mathrm{Pb}$ dan $\mathrm{Zn}$ yang diakibatkan pencemarandi wilayah tersebut.

Dari hasil identifikasi lokasi pembuangan sampah yang dilakukan pada berbagai area yang ada pada wilayah kajian diketahui bahwa pencemaran oleh sampah di wilayah kajian baik itu di area permukiman, tubuh air dan sekitar vegetasi mangrove memang terjadi. Hal ini potensial menimbulkan bahaya antropogenik bagi manusia dan organisme yang hidup di wilayah kajian jika tidak segera mendapatkan penangangan untuk pengelolaan sampah.

\section{KESIMPULAN}

Berdasarkan penelitian yang dilakukan pada wilayah kajian diketahui bahwa identifikasi terhadap lokasi pembuangan sampah di sebagian Muara Angke, Jakarta dapat dilakukan dengan metode interpretasi visual terhadap data penginderaan jauh udara dengan resolusi spasial sangat tinggi. Dari hasil identifikasi yang dilakukan diketahui bahwa pencemaran oleh sampah terjadi di permukiman dan tubuh air yang merupakan bagian bentuklahan fluvio-marin. Hal ini berpotensi menimbulkan bahaya antropogenik bagi manusia dan organisme yang ada wilayah tersebut.

\section{UCAPAN TERIMA KASIH}

Diucapkan terima kasih kepada Lembaga Pengelola Dana Pendidikan (LPDP) Kementerian Keuangan Republik Indonesia selaku penyandang dana penelitian, Kepala Pusat Teknologi Penerbangan LAPAN atas kesempatan pemanfaatan data kamera LAPAN Surveillance UAV dan kepada Bapak Prof. Dr. Dony Kushardono atas bimbingan dalam mengerjakan penelitian ini.

\section{DAFTAR PUSTAKA}

Andriani, G. F., \& Walsh, N. (2009). An example of the effects of anthropogenic changes on natural environment in the Apulian karst (southern Italy). Environmental Geology, 58, 313-325. https://doi.org/10.1007/s00254-008-1604-6

Astuti, M. D., \& Farda, N. M. (2015). Pemanfaatan citra Quickbird dan Sistem Informasi Geografi untuk mengetahui tingkat kemacetan lalu lintas sebagian Kota Semarang (studi kasus: Kec. Padurungan, Gayamsari, dan Semarang Selatan). Jurnal Bumi Indonesia, 4(4), 1-9.

Audina, M., Anwar, S., \& Antomi, Y. (2018). Prediksi dan Analisis Tempat Pembuangan Akhir (TPA) Sampah di Kota Padang. Prosiding Seminar Nasional Penginderaan Jauh, 548-556.

Ben-yosef, G., Assif, L., \& Ullman, S. (2018). Full interpretation of minimal images. Cognition, 171, 65-84. https://doi.org/10.1016/j.cognition.2017.10.006

Bonacci, O. (2004). Hazards caused by natural and anthropogenic changes of catchment area in karst. Natural Hazards and Earth System Sciences, 4, 655-661.

Day, M. J. (2007). Natural and anthropogenic hazards in the karst of Jamaica. In Natural and Anthropogenic Hazards in Karst Areas: Recognition, Analysis and Mitigation (pp. 173-184).

$\mathrm{Du}, \mathrm{R}$. (2016). Urban growth: Changes, management, and problems in large cities of Southeast China. Frontiers of Architectural Research, 5(3), 290-300. https://doi.org/10.1016/j.foar.2016.04.002

Farizki, M., \& Anurogo, W. (2017). Pemetaan Kualitas Permukiman dengan Menggunakan Penginderaan Jauh dan SIG di. Majalah Geografi Indonesia, 31(1), 39-45.

Hamzah, F., \& Setiawan, A. (2010). Akumulasi logam berat $\mathrm{Pb}, \mathrm{Cu}$, dan $\mathrm{Zn}$ di hutan mangrove Muara Angke, Jakarta Utara. Jurnal Ilmu Dan Teknologi Kelautan Tropis, 2(2), 41-52.

Jha, M. K. (2010). Natural and Anthropogenic Disasters: An Overview. Natural and Anthropogenic Disasters, 116.

Lakshmi, M. R., \& Kumar, V. D. (2015). Anthropogenic hazard and disaster relief operations : A case study of GAIL pipeline blaze in east Godavari of A . P. Procedia - Social and Behavioral Sciences, 189, 198-207. https://doi.org/10.1016/j.sbspro.2015.03.215 
Lozoya, J. P., Sarda, R., \& Jimenez, J. A. (2011). A methodological framework for multi-hazard risk assessment in beaches. Environmental Science \& Policy, 14, 685-696. https://doi.org/10.1016/j.envsci.2011.05.002

Mulasari, A., Husodo, A. H., \& Muhadjir, N. (2016). Analisis situasi permasalahan sampah Kota Yogyakarta dan kebijakan penanggulangannya. Jurnal Kesehatan Masyarakat, 11(2).

Parise, M., Waele, J. De, \& Gutierrez, F. (2009). Current perspectives on the environmental impacts and hazards in karst. Environmental Geology, 58, 235-237. https://doi.org/10.1007/s00254-008-1608-2

Pereira, L. C. C., Vila-concejo, A., da Costa, R. M., \& Short, A. D. (2014). Managing physical and anthropogenic hazards on macrotidal Amazon beaches. Ocean \& Coastal Management, 96, 149-162. https://doi.org/10.1016/j.ocecoaman.2014.05.008

Powers, M., James, M., Monson, E., Zimmerman, F. S., Einav, S., \& Dries, D. J. (2019). Anthropogenic Disasters. Critical Care Clinics, 35, 647-658.

Sari, N. M., \& Kushardono, D. (2016). Quality analysis of single tree object with OBIA and Vegetation Index. Geoplanning: Journal of Geomatics and Planning, 3(2), 93-106. https://doi.org/10.14710/geoplanning.3.2.93-106

Sari, N. M., \& Kushardono, D. (2019). Analisis dampak pembangunan infrastruktur Bandara Internasional Jawa Barat terhadap alih fungsi lahan pertanian melalui citra satelit resolusi tinggi. Jurnal Geografi, 11(2), 146-162. https://doi.org/10.24114/jg.v11i2.13470

Setiawan, F. (2010). Aplikasi penginderaan jauh dan GIS untuk penentuan lokasi TPA sampah di Kota Surabaya. Seminar Nasional Aplikasi Teknologi Informasi (SNATI), C14-C18.

Silviana, I. (2014). Hubungan Pengetahuan Ibu tentang Penyakit ISPA dengan Perilaku Pencegahan ISPA pada Balita di PHPT Muara Angke Jakarta Utara Tahun 2014. Forum Ilmiah, 11(3), 402-411.

Sinaga, J. H., Gunawan, T., \& Zuharnen. (2016). Aplikasi Citra Quickbird dan Sistem Informasi Geografis untuk kajian agihan permukiman kumuh di sebagian Kota Yogyakarta. Jumal Bumi Indonesia, 5(1), 1-9.

Yang, B., Zeng, F., Yuan, M., Li, D., Qiu, Y., \& Li, J. (2011). Measurement of Dongting Lake Area Based on Visual Interpretation of Polders. Procedia Environmental Sciences, 10, 2684-2689. https://doi.org/10.1016/j.proenv.2011.09.417 